\title{
Assessing Genetic Variability, Heritability and Genetic Advance in Rice (Oryza sativa L.) Under Sodic Soil
}

\author{
Shiv Prakash Shrivastav ${ }^{1}$, O. P. Verma ${ }^{1}$, Vishal Singh ${ }^{1}$, Kanhaiya Lal $^{2}$, \\ Amit Kumar Chaudhary ${ }^{1}$ and Suraj Kumar Hitaishi ${ }^{1}$
}

${ }^{1}$ Department of Genetics and Plant Breeding, Acharya Narendra Deva University of Agriculture and Technology, Narendra Nagar (Kumarganj), Ayodhya-224 229 (U.P.), India ${ }^{2}$ Department of Genetics and Plant Breeding, CSA University of Agriculture and Technology, Kanpur, Uttar Pradesh, India

*Corresponding author

\section{A B S T R A C T}

The experiment on 110 genotypes (aromatic and non-aromatic rice) along with three checks viz., Sarjoo 52, FL 478 and CSR 10 of rice (Oryza sativa L.) was conducted to work out the genetic variability, heritability and genetic advance effects of their various

\section{Keywords}

Rice (Oryza sativa L.), genetic variability, heritability, genetic advance, grain yield and sodic soil

Article Info

\section{Accepted:}

25 January 2019

Available Online:

10 February 2020 attributes on grain yield. The high estimates $(>20 \%)$ of phenotypic (PCV) and genotypic (GCV) coefficients of variation were recorded in case of grains per panicle $(\mathrm{PCV}=28.201 \%, \mathrm{GCV}=28.147 \%)$, spikelets per panicle $(\mathrm{PCV}=26.220 \%, \mathrm{GCV}=26.187 \%)$, flag leaf area $(\mathrm{PCV}=26.199 \%, \mathrm{GCV}=25.084 \%)$, biological yield per plant $(\mathrm{PCV}=23.935 \%$, GCV $=23.870 \%)$ and grain yield per plant (PCV=21.375\%, $\mathrm{GCV}=21.245 \%)$. High estimates of broad sense heritability $(>75 \%)$ were recorded for spikelets/panicle (99.75\%), grains/panicle (99.62\%), biological yield/plant (99.46\%), 1000 -grain weight $(99.29 \%)$, days to $50 \%$ flowering $(99.26 \%)$, grain yield/plant (98.79\%), panicle length $(98.22 \%)$, spikelet fertility $(96.86 \%)$, harvest index $(95.70 \%)$, chlorophyll content $(94.06 \%)$, leaf nitrogen $(91.90 \%)$, flag leaf area $(91.67 \%)$, L/B ratio $(79.31 \%)$ and leaf temperature $(77.92 \%)$. The high estimates of genetic advance in per cent of mean $(>20 \%)$ were recorded for grains/panicle $(57.8734 \%)$, spikelets/panicle $(53.8776 \%)$, flag leaf area $(49.4721 \%)$, biological yield/plant $(49.0373 \%)$, grain yield/plant (43.4988\%), leaf nitrogen $(29.1598 \%)$, L/B ratio $(23.1016 \%)$, panicle length $(21.1853 \%)$, panicle bearing tillers/plant $(20.5318 \%)$. High heritability and genetic advance indicate that the additive nature of gene action and reliability of those characters for selection and emerged as ideal traits for improvement through selection.

\section{Introduction}

Rice (Oryza sativa L.) is the most important staple food crop of the world. Rice belongs to family Gramineae (Poaceae), chromosome number $2 \mathrm{n}=24 \quad(\mathrm{n}=12)$ and basic chromosome number $\mathrm{x}=5$ (Due to meiotic irregularity in chromosome number 2). The cultivated rice belongs to genus Oryza and there are about 24 species of rice distributed in tropical, sub-tropical and warm temperate regions of the world. Out of these, most 
commonly cultivated species are Oryza sativa and Oryza glaberrima. The Oryza sativa is divided into three sub-species, namely, Indica, Japonica and Javonica.

To focus attention on the importance of rice in global food security and the necessity to increase rice production and productivity, United Nations General Assembly in 2002 declared to celebrate the year 2004 as "International Year of Rice (IYR 2004)" with the theme of "Rice is Life". Rice, being the staple food for more than 70 per cent of our national population and source of livelihood for 120-150 million rural households, is backbone to the Indian Agriculture.

\section{Main Rice growing countries in the world}

The area, production and productivity of first five highest producing countries of rice in the world are given below:

\begin{tabular}{|c|c|c|c|r|}
\hline Country & Area (million ha) & Production (million tonnes) & Productivity (kg/ha) & Productivity $\mathbf{~} \mathbf{0}$ \\
\hline 1. China & 30.58 & 205.21 & 1710 & 27.70 \\
\hline 2. India & 43.86 & 104.80 & 2390 & 21.81 \\
\hline 3. Indonesia & 13.84 & 71.29 & 5152 & 9.62 \\
\hline 4. Bangladesh & 11.78 & 51.50 & 4376 & 6.95 \\
\hline 5. Vietnam & 7.90 & 4404 & 5573 & 5.94 \\
\hline Total & 107.96 & 476.84 & 4417 & \\
\hline
\end{tabular}

Source: Agricultural statistics at a glance 2015

India has the largest area 43.39 million hectare constituting $28.01 \%$ of the land under rice in the world and rank second in total production 111.50 million tonnes next to China (187.490 millon tonnes) with an average productivity of 2804 $\mathrm{Kg} /$ hectare(Anonymous 2017-18). Asia has an area of only 140.036 million hectare and productivity as 5.32 tonns/ hectare (Anonymous 2017-18). More than $80 \%$ of our populations depend fully or partially on rice as their main food and staple diet.

Uttar Pradesh is important rice growing state of the country. The area and production of rice in this state is about 6.45 million hectare and 18.251 millon tonnes, respectively with the productivity of 4.95 tonnes/ hectare (Uttar Pradesh directorate of agricultural ministry, 2017-18). Agriculture is the most important in the state, because, about $80 \%$ of its population resides in rural areas and $75 \%$ of the total workers are involved directly or indirectly in cultivation/farming which accounts for $27 \%$ of state's GDP. Agriculture is the main source of income for families in the state.

Although, the average productivity of rice is much lower in India than the average productivity at world level, the development of high yielding widely adapted pure line rice varieties coupled with advances in production technology in past four decades has enabled us to cope with the demand of rice to a satisfactory level. However, rapidly increasing demand due to ever increasing Indian population has forced us to search for another quantum jump in rice productivity. The projection of India's rice production target for $2020 \mathrm{AD}$ is $115-120$ million tonnes, which can be achieved only by increasing the rice production by over 2.0 million tonnes per year in the coming decades (Viraktamath and Shobha Rani, 2008). This has to be done against the backdrop of diminishing natural resource bases like land, labour and water, which is a huge challenge (Subaiah, 2006). Thus, development of improved high yielding 
pure line and hybrid rice varieties suitable for adverse condition (salt affected soil) would be an important strategy to meet this challenge. Utter Pradesh inland salinity areas are mainly concentrated in Raibareilly, Azamgarh, Sultanpur, Faizabad, Lucknow, Unnao and Pratapgarh districts.

Considering the overall scenario at country as well as world level in respect of demand and requires supply of rice, it need based aim for developing high yielding pure line as well as commercial hybrid varieties of aromatic and non-aromatic rice so that rice can fulfill its potential not only in overcoming the hunger in the country through high yielding nonaromatic rice but also in improving the socioeconomic condition of Indian farmers through the benefits of cultivating more numerative aromatic rice.

Aromatic rice constitutes a small but special sub-group of rice which is considered best in quality. Aromatic rice is cultivated in the traditional areas of North Western parts of Indian sub-continent for many centuries.

The grain of aromatic rice when cooked emits pleasant odour but this character is found only in the basmati varieties. Aroma is the major character for any improvement in aromatic rice. Basmati rice is glutinous rice that has been cultivated at foothills of Himalayan mountain range in India for centuries. It is non-allergic food, rich in complex carbohydrates and low in salts and fats. The fine grain basmati varieties of rice are considered high quality rice and fetch a high price in the national and international trade. However, yield per unite area of basmati rice is very low due to tall plant habit and late maturity. Most of the available scented rice varieties in India have low yield and narrow adaptability.

In order to step up the production potential, there is, thus, an urgent need to launch a dynamic breeding programme to develop improved non-aromatic and aromatic rice varieties suitable for different agro-climatic regions. For planning and execution of a successful breeding programme, the most essential pre-requite is the availability of substantial desirable genetic variability for important characters in the germplasm collections of the plant species in question. Germplasm serves as most valuable natural reservoir in providing needed attributes for engineering successful varieties (Hawkes, 1981).

The presence of desirable variability in germplasm collections enables breeders to recombine favorable phenotypes of different traits to develop improved genotypes capable of producing high and stable yield. Therefore, it becomes imperative to evaluate the available germplasm and assess the existing genetic variability for agronomically important traits so that breeders may know which few of the numerous accessions available in the germplasm collections would be useful for serving the breeding objective. In absence of such information, it would be very difficult to launch a systematic breeding programme consuming optimum time and resources. Therefore, an attempt was made to evaluate a germplasm collection of aromatic and non-aromatic rice and examine the level of genetic variability to work out an efficient selection criterion. The available variability in a population can be partitioned into heritable and non-heritable components with the aid of genetic parameters such as coefficients of variation, heritability and genetic advance to serve as basis for selection of some outstanding genotypes than existing ones.

The assessment of genetic divergence existing in the germplasm collections is very important for success of hybridization programme leading to development of high yielding varieties of crop plants because 
optimum magnitude of parental diversity is required for generating superior hybrids for commercial exploitation as well as transgressive segregants in segregating generations. The assessment of genetic diversity in the germplasm collections under study was carried out by employing Nonhierarchical Euclidean cluster analysis.

Salt affected areas have increased day by day because of excessive use of irrigation water with improper drainage coupled with the poor quality irrigation water. Development of varieties for underutilized soil is the only option to increase the production. Thus, adoption of high yielding rice varieties to various stress environment and underutilized land such as salt affected soil would be an important strategy to meet this challenge. The salt tolerant rice varieties are sparse and for the development of high yielding pure line and hybrid varieties in rice, the information on various genetic aspects in respect to important plant characters is essential for planning and execution of a successful breeding programme.

The understanding of genetic architecture and direct and indirect selection parameters of agronomically important traits helps in deciding the type of variety to be developed and the breeding methodology to be followed in a particular growing situation.

In order to develop high yield pure line rice varieties, it is essential to screen germplasm lines for gene action, combining ability and nature and magnitude of heterosis for different characters which is prerequisite for identification of potential rice varieties for the adverse soil conditions (salt affected soil). Although, the information on above aspects in rice is available, but most of these studies are based on irrigated and normal soil conditions and literature based on salinity conditions are meagre. Therefore, further studies aimed at generating and comparing information on above aspects in rice, are warranted to facilitate development of high yielding rice cultivars for above ecosystem.

\section{Materials and Methods}

The study was designed to work out the status of association of different grain yield traits on grain yield per plant among 110 genotypes (aromatic and non-aromatic rice) at field experiment under present investigation was conducted during Kharif,2018 at the Main Experimental Station of A.N.D. University of Agriculture \& Technology, Narendra Nagar (Kumarganj), Ayodhya, India.

The experimental materials of studies comprised of 110 genotypes with three check varieties viz., Sarjoo 52, FL 478 and CSR 10. The experiment was laid out in augmented design. The observation were recorded on sixteen different grain yield traits viz., days to $50 \%$ flowering, chlorophyll content, leaf nitrogen, leaf temperature, flag leaf area $(\mathrm{cm})$, plant height $(\mathrm{cm})$, panicle bearing tillers per plant, panicle length $(\mathrm{cm})$, spikelets per panicle, grains per panicle, spikelet fertility $(\%)$, biological yield per plant $(\mathrm{g})$, harvestindex (\%),L:B ratio, 1000-grain weight (g) and grain yield per plant $(\mathrm{g})$. The certain selected statistical approaches were used for data analysis.

Analysis of variance for Augmented Design by Federer (1956). Phenotypic (PCV), genotypic (GCV) and environmental (ECV) coefficients of variation for different characters were estimated by formulae suggested by Burton and de Vane (1953). Heritability in broad sense $\left(\mathrm{h}^{2} \mathrm{~b}\right)$ was calculated as suggested by Hanson et.al. (1956).

The expected genetic advance (Ga) was estimated using formula suggested by Johnson et al., (1955). 


\section{Results and Discussion}

The success of selection in improving plant characters depends mainly on presence substantial genetic variability and nature of heritability and gene action. The genetic variability is the raw material of plant breeding programme on which selection acts to evolve superior genotypes.

The phenotypic, genotypic and environmental coefficients of variation can be used for assessing and comparing the nature and magnitude of variability existing for different characters in the breeding materials.

Heritability in broad sense quantifies the proportion of heritable genetic variance to total phenotypic variance, while heritability in narrow sense represents the ratio of fixable additive genetic variance to total phenotypic variance.

Estimates of heritability help in estimating expected progress through selection. The genetic advance in per cent of mean provides indication of expected selection response by taking into account the existing genetic variability and heritability of the character.

\section{Analysis of variance}

Analysis of variance for augmented design was carried out for sixteen characters to test the significance of differences among various treatments (checks) and is presented in Table 1. The mean squares due to checks were highly significant for all the fourteen characters except chlorophyll content and panicle bearing tiller per plant while mean squares due to blocks were highly significant for all the fifteen characters except panicle bearing tillers per plant. The mean squares due to blocks were significant for only panicle bearing tillers per plant.

\section{Coefficient of variation}

The phenotypic and genotypic coefficients of variation for all the sixteen characters have been given in Table 2. In general, the magnitude of phenotypic coefficient of variation was higher than corresponding genotypic coefficient of variation for all the characters.

The high estimates (>20\%) of phenotypic (PCV) and genotypic (GCV) coefficients of variation were recorded in case of grains per panicle $(\mathrm{PCV}=28.201 \%, \quad \mathrm{GCV}=28.147 \%)$, spikelets per panicle (PCV $=26.220 \%$, $\mathrm{GCV}=26.187 \%)$, flage leaf area $(\mathrm{PCV}=26.199$ $\%, \mathrm{GCV}=25.084 \%$ ), biological yield per plant ( $\mathrm{PCV}=23.935 \%, \mathrm{GCV}=23.870 \%)$ and grain yield per plant $(\mathrm{PCV}=21.375 \%$, $\mathrm{GCV}=21.245 \%)$.

Moderates estimates $(<20 \%->10 \%)$ of PCV and GCV were noted for panicle bearing tillers per plant (PCV $=17.037 \%$, $\mathrm{GCV}=13.031 \%$ ), leaf nitrogen (PCV $=15.403 \%, \mathrm{GCV}=14.766 \%), \mathrm{L} / \mathrm{B}$ ratio (PCV $=14.141 \%, \mathrm{GCV}=12.593 \%)$, plant hight (PCV $=11.564 \%, \quad \mathrm{GCV}=9.191 \%)$, panicle length (PCV $=10.470 \%, \mathrm{GCV}=10.377 \%)$ and chlorophyll content $\quad(\mathrm{PCV}=10.106 \%$, $\mathrm{GCV}=9.801 \%)$.

The low estimates $(<10 \%)$ of phenotypic and genotypic coefficients of variations were observed for harvest index (PCV=9.882\%, $\mathrm{GCV}=9.667 \%)$, 1000-grains weight $(\mathrm{PCV}=8.679 \%, \mathrm{GCV}=8.649 \%)$, days to $50 \%$ flowering $\quad(\mathrm{PCV}=6.672 \%, \quad \mathrm{GCV}=6.647 \%)$, spikelet fertility (PCV=6.115\%, $\mathrm{GCV}=6.018 \%)$ and leaf temperature $(\mathrm{PCV}=3.756 \%, \mathrm{GCV}=3.315 \%)$. 
Table.1 Analysis of variance of augmented design for 16 characters in rice genotypes

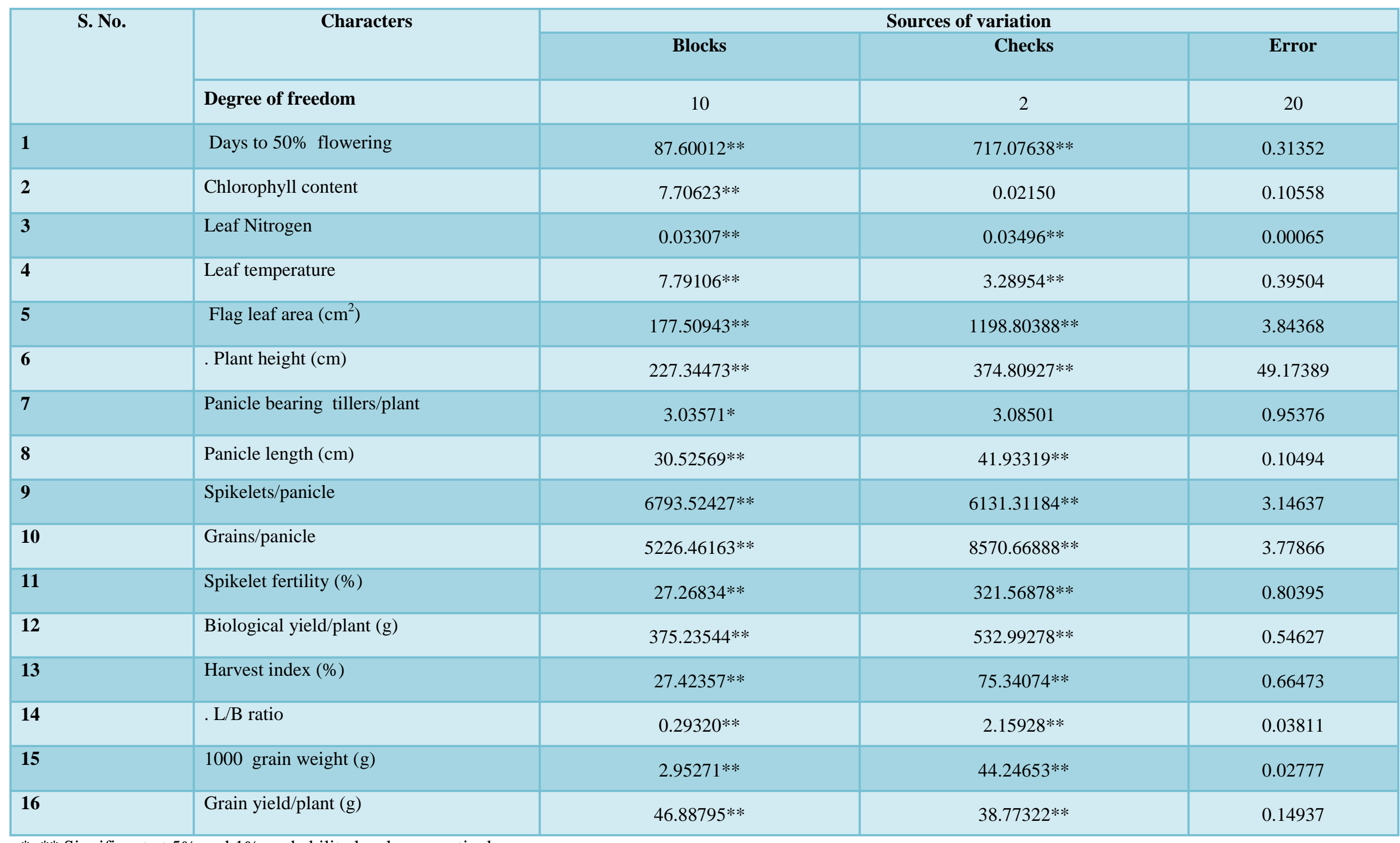

*, ** Significant at $5 \%$ and $1 \%$ probability levels, respectively 
Table.2 Estimates of coefficient of variation, $\mathrm{h}_{(\mathrm{bs})}{ }^{2}$ (broad sense) and genetic advance in per cent of mean for 16 characters in rice

\begin{tabular}{|c|c|c|c|c|c|c|c|}
\hline \multirow{2}{*}{$\begin{array}{l}\text { S. } \\
\text { No. }\end{array}$} & \multirow[t]{2}{*}{ Characters } & \multirow[t]{2}{*}{ Range } & \multirow[b]{2}{*}{ Mean } & \multicolumn{2}{|c|}{ Coefficient of variation } & \multirow{2}{*}{$\begin{array}{l}\text { Heritability } \\
\text { in broad } \\
\text { sense }(\%)\end{array}$} & \multirow{2}{*}{$\begin{array}{l}\text { Genetic advance } \\
\text { in per cent of } \\
\text { mean }\end{array}$} \\
\hline & & & & PCV & GCV & & \\
\hline 1 & Days to $50 \%$ flowering & $80.205-117.219$ & 97.468 & 6.672 & 6.647 & 99.26 & 13.6421 \\
\hline 2 & Chlorophyll content & $7.022-16.389$ & 13.202 & 10.106 & 9.801 & 94.06 & 19.5807 \\
\hline 3 & Leaf Nitrogen & $0.358-0.794$ & 0.581 & 15.403 & 14.766 & 91.90 & 29.1598 \\
\hline 4 & Leaf temperature & $28.827-39.054$ & 35.630 & 3.756 & 3.315 & 77.92 & 6.0288 \\
\hline 5 & Flag leaf area $\left(\mathrm{cm}^{2}\right)$ & $10.981-46.698$ & 26.121 & 26.199 & 25.084 & 91.67 & 49.4721 \\
\hline 6 & Plant height $(\mathrm{cm})$ & $63.830-165.593$ & 99.589 & 11.564 & 9.191 & 63.17 & 15.0485 \\
\hline 7 & $\begin{array}{l}\text { Panicle bearing tillers/ } \\
\text { plant }\end{array}$ & $5.409-14.056$ & 8.905 & 17.037 & 13.031 & 58.50 & 20.5318 \\
\hline 8 & Panicle length $(\mathrm{cm})$ & $17.138-29.658$ & 23.184 & 10.470 & 10.377 & 98.22 & 21.1853 \\
\hline 9 & Spikelets/panicle & $59.321-242.401$ & 135.224 & 26.220 & 26.187 & 99.75 & 53.8776 \\
\hline 10 & Grains/panicle & $47.092-197.025$ & 112.264 & 28.201 & 28.147 & 99.62 & 57.8734 \\
\hline 11 & Spikelet fertility (\%) & $64.514-96.509$ & 82.695 & 6.115 & 6.018 & 96.86 & 12.2015 \\
\hline 12 & Biological yield/plant $(\mathrm{g})$ & $20.822-64.472$ & 42.205 & 23.935 & 23.870 & 99.46 & 49.0373 \\
\hline 13 & Harvest index $(\%)$ & $29.255-51.858$ & 39.614 & 9.882 & 9.667 & 95.70 & 19.4808 \\
\hline 14 & L/B ratio & $2.197-5.133$ & 3.026 & 14.141 & 12.593 & 79.31 & 23.1016 \\
\hline 15 & 1000 grain weight $(\mathrm{g})$ & $14.678-30.358$ & 22.856 & 8.679 & 8.649 & 99.29 & 17.7534 \\
\hline 16 & Grain yield/plant $(\mathrm{g})$ & $8.898-24.658$ & 16.464 & 21.375 & 21.245 & 98.79 & 43.4988 \\
\hline
\end{tabular}

\section{Heritability and genetic advance}

Heritability in broad sense and genetic advance in per cent of mean for all the sixteen yield contributing traits were estimated and findings have been depicted in Table 2. High estimates of broad sense heritability (> 75\%) were recorded for spikelets/panicle $(99.75 \%)$, grains/panicle $(99.62 \%), \quad$ biological yield/plant (99.46\%), 1000-grain weight (99.29\%), days to $50 \%$ flowering $(99.26 \%)$, grain yield/plant $(98.79 \%)$, panicle length (98.22\%), spikelet fertility (96.86\%), harvest index(95.70\%), chlorophyll content $(94.06 \%)$, leaf nitrogen $(91.90 \%)$, flag leaf area $(91.67 \%), \mathrm{L} / \mathrm{B}$ ratio $(79.31 \%)$ and leaf temperature $(77.92 \%)$.

The moderate estimates of heritability (50$75 \%$ ) were observed for plant height $(63.17 \%)$, and panicle bearing tillers/plant $(58.50 \%)$ while none of the traits showed low estimates of broad sense heritability.
The high estimates of genetic advance in per cent of mean $(>20 \%)$ were recorded for grains/panicle $(57.8734 \%)$, spikelets/panicle $(53.8776 \%)$, flag leaf area $(49.4721 \%)$, biological yield/plant $(49.0373 \%)$, grain yield/plant (43.4988\%), leaf nitrogen $(29.1598 \%)$, L/B ratio $(23.1016 \%)$, panicle length $(21.1853 \%)$, panicle bearing tillers/plant (20.5318\%), while the chlorophyll content (19.5807\%), harvest index (19.4808\%), 1000-grain weight $(17.7534 \%)$, plant height $(15.0485 \%)$, spikelet fertility $(12.2015 \%)$, days to $50 \%$ flowering (13.6421\%) and leaf temperature $(6.0228 \%)$ showed low estimate of genetic advance in per cent of mean.

The high to very high estimates of direct selection parameters for above mentioned nine characters indicated that these would be ideal traits for improvement through selection in context of materials evaluated owing to existence of high genetic variability represented by high coefficients of variation 
and high transmissibility denoted by high heritability for them.

The high estimates of direct selection parameters observed for the above characters are broadly in agreement with earlier reports in rice (Anjaneyulu et al., 2010; Dhanwani et al., 2013; Lingaiah et al., 2014; Gyawali et al., 2018; Parimala and Devi 2019).

Panicle length having moderate PCV and GCV values with high heritability resulted into high genetic advance to suggest that reasonable response to selection may be obtained for this character owing to high transmissibility even if variability happens to be moderate.

Inspite of recording high heritability in broad sense, days to $50 \%$ flowering resulted low genetic advance owing to low variability represented by low value of PCV and GCV which indicated that improving trait through selection in context of present material would be difficult due to lack of genetic variability.

\section{References}

Anjaneyulu, M.; Reddy, D.R. and Reddy, K.H.P. (2010). Genetic variability, heritability and genetic advance in rice (Oryza sativa L.). Res. on Crop.,11(2):415-416.

Anonymous, (2017-18). Directorate of economics and statistics, dept. of agriculture and cooperation. Ministry of agriculture. Government of India.

Burton, G. M. and de Vane, E. H. (1953). Estimating heritability in tall fescue (Festuca arundinacea) from replicated clonal material. Agron. J., 45: 471-481.

\section{How to cite this article:}

Shiv Prakash Shrivastav, O. P. Verma, Vishal Singh, Kanhaiya Lal, Amit Kumar Chaudhary and Suraj Kumar Hitaishi. 2020. Assessing Genetic Variability, Heritability and Genetic Advance in Rice (Oryza sativa L.) Under Sodic Soil. Int.J.Curr.Microbiol.App.Sci. 9(02): 3108-3115. doi: https://doi.org/10.20546/ijcmas.2020.902.359 